\title{
Perbandingan Kinerja Bank Syariah dan Bank Non Syariah
}

Amelia Oktrivina Diapari Siregar ${ }^{1}$

${ }^{1}$ Universitas Pancasila, Jl. Raya Lenteng Agung, Jagajarsa, Jakarta Selatan, 12640

I N F O A R T I K E L

\section{JEL Classification:}

G14

G10

\section{Keywords:}

financial performance,

islamic banking,

conventional banks.

\section{A B S T R A C T}

The purpose of this study was to determine and measure the performance comparison between Islamic banks with conventional banks are seen by CAR, $R O A, L D R, N P L$, and ROA. The research data was obtained from the financial statements listed in Indonesia Stock Exchange in 2012 - 2013. The results showed that there are significant differences between Islamic banks with conventional banks if measured by ROA, LDR, NPL, and BOPO while the CAR no significant difference between islamic banks with conventional banks. Based on research results Islamic banks overall average of the ratio used shows that the CAR, LDR, NPL, and BOPO greater than conventional banks. While conventional banks have an average ROA, and BOPO higher than islamic banks while the average CAR, LDR, and NPL better than islamic banks means that the good performance of the conventional banks because even though banks have low capital and low lending to customers this has resulted in low non performing loans in the bank so that the bank has a high income.

\section{A B S T R A K}

Tujuan penelitian ini adalah untuk mengetahui perbandingan kinerja bank syariah dengan bank konvensional dilihat berdasarkan rasio CAR, ROA, LDR, NPL, dan BOPO. Data penelitian ini diperoleh dari laporan keuangan yang terdaftar di Bursa Efek Indonesia tahun 2012-2013. Hasil penelitian menunjukkan bahwa terdapat perbedaan yang signifikan antara bank syariah dengan bank konvensional jika diukur dengan rasio ROA, LDR, NPL, dan BOPO sedangkan rasio CAR tidak terdapat perbedaan yang signifikan antara bank syariah dengan bank konvensional. Berdasarkan hasil penelitian bank syariah mempunyai rata - rata secara keseluruhan dari rasio yang digunakan menunjukkan bahwa rasio CAR, LDR, NPL, dan BOPO lebih besar dibandingkan dengan bank konvensional. Sedangkan bank konvensional mempunyai rata - rata rasio ROA, dan BOPO lebih tinggi dibandingkan bank syariah sedangkan rata - rata rasio CAR, LDR, dan NPL lebih rendah dibandingkan bank syariah, artinya bahwa kinerja bank konvensional bagus karena meskipun bank memiliki modal yang rendah dan rendahnya pemberian kredit kepada nasabah hal ini yang mengakibatkan rendahnya kredit bermasalah pada bank sehingga bank mempunyai pendapatan yang tinggi.

\section{Pendahuluan}

Kinerja (kondisi keuangan) bank adalah salah satu faktor yang harus diperhatikan oleh bank untuk bisa terus bertahan hidup. Kinerja keuangan bank merupakan bagian dari kinerja bank secara keseluruhan. Kinerja bank secara keseluruhan merupakan gambaran prestasi yang dicapai bank dalam operasionalnya, baik

*Email Korespondensi: ${ }^{1}$ siregaramelia379@yahoo.com 
menyangkut aspek keuangan, pemasaran, penghimpunan dan penyaluran dana, teknologi, maupun sumber daya manusia. (Widiyanti dan Wulansari, 2015).

Berdasarkan kinerja bank-bank syariah dan per-kembangannya pada saat ini akan dikembangkan suatu standar khusus untuk perbankan syariah semacam Basel Accord II yang diterapkan oleh bank konvensional. Menurut Deputi Gubernur Bank Indonesia Basel Accord II merupakan pedoman internasional yang berlaku bagi perbankan nasional dalam mengelola resiko pasar nasional maupun internasional. Apalagi setelah dikeluarkannya fatwa Majelis Ulama Indonesia (MUI) pada tanggal 16 Desember 2003 bahwa bunga bank itu diharamkan, hal ini menimbulkan dampak positif bagi perbankan konvensional seperti masyarakat semakin gencar menanamkan dananya pada bank syariah sehingga semakin meningkatnya dana dari pihak ketiga.

Pengakuan pendapatan bagi hasil yang diterapkan bank syariah melalui pembiayaan dengan akad mudharabah dan pengakuan pendapatan bunga kredit pada bank konvensional. Hingga Juni 2013 sebesar 75,98\% dari pembiayaan perbankan syariah menggunakan akad Murabahah. Sementara, pembiayaan berbasis akad Mudharabah-Musyarakah berkontribusi $2,96 \%$ dari total perbankan syariah.

Laporan keuangan akan dapat dihitung sejumlah rasio keuangan yang lazim dijadikan dasar penilaian tingkat kesehatan bank. Analisis rasio keuangan memungkinkan manajemen untuk mengidentifikasikan perubahan-perubahan pokok pada trend jumlah, dan hubungan serta alas an perubahan tersebut. Hasil analisis laporan keuangan akan membantu mengintepretasikan berbagai hubungan serta kecenderungan yang dapat memberikan dasar pertimbangan mengenai potensi keberhasilan perusahaan dimasa mendatang.

Untuk menilai kinerja perusahaan perbankan umumnya digunakan aspek penilaian, yaitu: Capital, Assets, Management, Earnings, dan Liquidity yang biasa disebut CAMEL. Aspekaspek tersebut menggunakan rasio keuangan. Hal ini menunjukan bahwa rasio keuangan dapat digunakan untuk menilai tingkat kesehatan bank

\section{Telaah Teori dan Pengembangan Hipotesis}

\section{Bank Konvensional}

Bank konvensional adalah bank yang menjalankan kegiatan usahanya secara konvensional dan berdasarkan jenisnya terdiri dari bank umum konvensional dan bank perkreditan rakyat (BPR). (Hasibuan, 2007; Bank Indonesia, 2007; 2011)

a. Kegiatan Usaha Bank Konvensional Kegiatan usaha bank konvensional terdiri atas:

1. Menghimpun dana dari masyarakat dalam bentuk simpanan berupa giro, deposito berjangka, sertifikat deposito, tabungan dan bentuk lainnya.

2. Memberikan kredit.

3. Menerbitkan surat pengakuan hutang.

4. Membeli, menjual atau meminjam atas resiko sendiri maupun kepentingan atas nasabahnya.

5. Memindahkan uang baik untuk kepentingan sendiri maupun untuk kepentingan nasabahnya.

b. Larangan Kegiatan Usaha Bank Konvensional

1. Melakukan usaha perasuransian

2. Melakukan penyertaan modal

c. Prinsip Bank Konvensional, mencakup:

1. Melakukan investasi baik yang halal atau haram menurut hukum Islam.

2. Memakai perangkat suku bunga.

3. Berorientasi keuntungan.

4. Hubungan dengan nasabah dalam bentuk kreditur-debitur.

5. Penghimpunan dan penyaluran dana tidak diatur oleh dewan sejenis.

d. Penilaian Tingkat Kesehatan Bank Umum

Konvensional

Bank wajib memelihara dan/atau meningkatkan tingkat kesehatan bank dengan menerapkan prinsip kehati-hatian dan manajemen risiko dalam melaksanakan kegiatan usaha. Bank wajib melakukan penilaian tingkat kesehatan dengan menggunakan pendekatan risiko (Riskbased Bank Rating) baik secara individual 
maupun secara konsolidasi (Kasmir, 2010) Bank wajib melakukan penilaian sendiri (self assessment) atas tingkat kesehatan bank paling kurang setiap semester untuk posisi akhir bulan Juni dan Desember. Bank wajib melakukan pengkinian self assesment tingkat kesehatan bank sewaktu-waktu apabila diperlukan.

Faktor-faktor penilaian tingkat kesehatan bank meliputi:

1. Profil risiko (risk profile)

2. Good Corporate Governance (GCG)

3. Rentabilitas (earnings) dan

4. Permodalan (capital).

Peringkat Komposit (PK) tingkat kesehatan bank ditetapkan berdasarkan analisis secara komprehensif dan terstruktur terhadap peringkat setiap faktor dengan memperhatikan materialitas dan signifikansi masing-masing faktor, serta mempertimbangkan kemampuan bank dalam menghadapi perubahan kondisi eksternal yang signifikan.

\section{Bank Syariah}

Bank syariah adalah bank yang beroperasi dengan tidak mengandalkan pada bunga. Atau lembaga keuangan yang usaha pokoknya memberikan pembiayaan dan jasa-jasa lainnya dalam lalu lintas pembayaran serta peredaran uang yang pengoperasiannya disesuaikan dengan prinsip syariat islam. Prinsip syariah adalah prinsip hukum islam dalam kegiatan perbankan berdasarkan fatwa yang dikeluarkan oleh lembaga yang memiliki kewanangan dalam penetapan fatwa di bidang syariah.

Penilaian tingkat kesehatan BUS mencakup penilaianterhadap faktor-faktorsebagai berikut permodalan, kualitas aset, manajemen, rentabilitas, likuiditas, dan sensitivitas terhadap risiko pasar. (Herman, 2011; Pandia, 2012; Muhammad, 2014)

1. Penilaian peringkat komponen atau rasio keuangan pembentuk faktor permodalan, kualitas aset, rentabilitas, likuiditas, dan sensitivitas terhadap risiko pasar dihitung secara kuantitatif;

2. Penilaian peringkat komponen pembentuk faktor manajemen dilakukan melalui analisis dengan mempertimbangkan indikator pendukung dan unsur judgement; dan

3. Berdasarkan hasil penilaian peringkat faktor finansial dan penilaian peringkat faktor manajemen.

Penelitian tentang perbedaan kinerja keuangan bank pernah dilakukan oleh Yulianto (2009), Ningsih (2012), Parathon (2013), Putra, dkk(2014). Hasil riset Ningsih (2012) menemukan bukti empiris bahwa LDR dan ROA Bank syariah lebih tinggi dibandingkan bank umum, sedangkan rasio CAR, NPL, BOPO pada bank umum lebih tinggi dibandingkan bank syariah. Riset Putra, dkk (2014) tidak berhasil membuktikan adanya perbedaan ROA, ROE, CR (current ratio), QR (quick ratio) pada bank umum dan bank syariah, sementara price earning ratio (PER) terbukti secara signifikan berbeda.

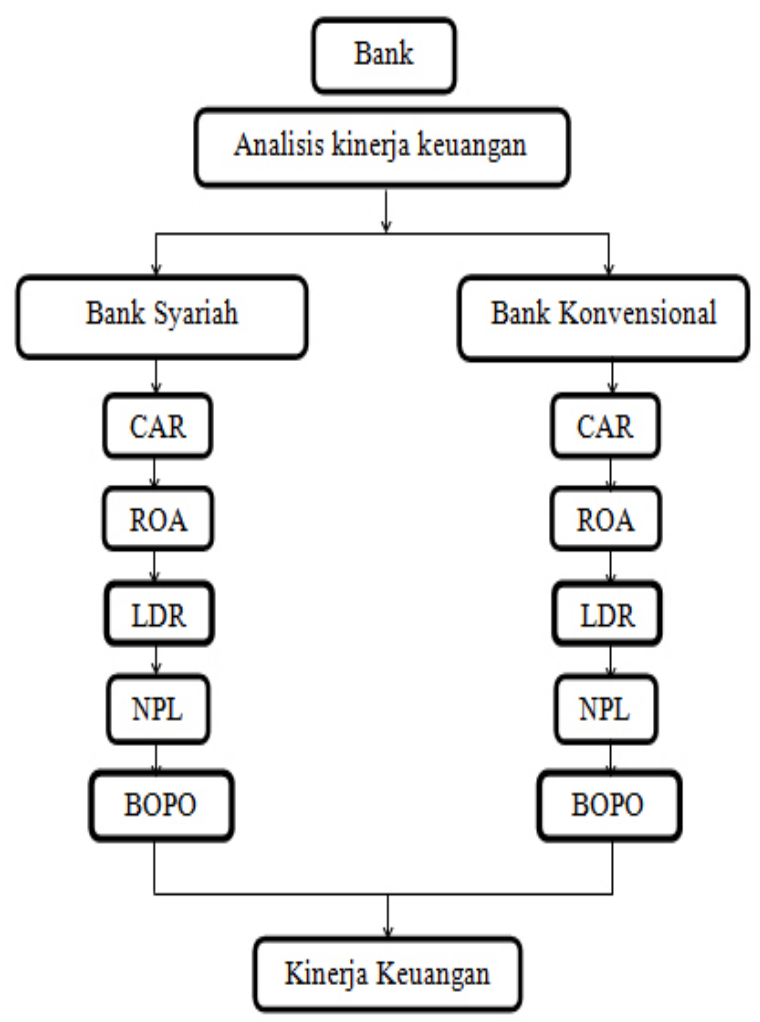

H1:Ada perbedaan yang signifikan antara kinerja keuangan bank syariah dengan bank konvensional.

\section{Metode}

Penelitian merupakan suatu proses atau 
tahapan yang dilakukan untuk menemukan suatu permasalahan melalui suatu studi yang komprehensif dan analisis berbagai fenomena dan kondisi yang ada. Tujuan dari penelitian ini adalah untuk mengetahui tingkat kinerja keuangan bank konvensional apabila dibandingkan dengan bank syariah. Kinerja keuangan bank yang dimaksud dalam penelitian ini adalah penilaian tingkat efisiensi dan produktifitas yang di lakukan secara berkala atas dasar laporan manajemen dan laporan keuangan yang merupakan pencerminan prestasi yang dicapai oleh bank..

Variabel merupakan objek penelitian yang menjadi titik perhatian dalam suatu penelitian. Operasional variabel adalah penarikan batasan yang lebih menjelaskan ciri-ciri spesifik yang lebih substantif dari suatu konsep. Tujuan operasional variabel adalah untuk dapat mencapai suatu alat ukur yang sesuai dengan hakikat variabel yang telah dijelaskan.

Adapun operasional variabel yang menjadi alat ukur analisis rasio keuangan dalam penilaian kinerja perbankan terdiri dari:

1. Capital Adequacy Ratio (CAR)

Rasio ini dirumuskan:

$\frac{\text { Modal }}{\text { Aktiva tertimbang menurut resiko }} \times 100 \%$

2. Return On Asset (ROA)

Rasio ini dapat dirumuskan :

$\frac{\text { Laba Sebelum Pajak }}{\text { Rata-rata Total Aset }} \times 100 \%$

3. Loan to Deposit Ratio (LDR)

Ratio ini dapat dirumuskan :

$\frac{\text { Kredit }}{\text { Dana Pihak Ketiga }} \times 100 \%$

4. Non Performing Loan (NPL)

Rasio ini dapat dirumuskan :

$$
\frac{\text { Total NPL }}{\text { Total Kredit }} \times 100 \%
$$

5. Beban Operasional dibagi Pendapatan

Operasional (BOPO)

Rasio ini dapat dirumuskan :

$\frac{\text { Total Beban Operasional }}{\text { Total Pendapatan Operasional }} \times 100 \%$

Data yang digunakan dalam penelitian ini adalah data sekunder. Data sekunder di- peroleh dari laporan keuangan tahunan bank konvensional dan bank syariah pada tahun 20122013 yang terdapat dalam Bursa Efek Indonesia. Teknik pengambilan sampel dalam penelitian ini menggunakan metode purposive sampling, yaitu cara pengambilan sampel dengan kriteria tertentu sesuai dengan data dan informasi yang diperlukan.

Adapun kriteria sampel dalam penelitian ini adalah sebagai berikut:

a. Bank konvensional dan bank syariah yang mempublikasikan laporan keuangan tahunan pada tahun 2012-2013.

b. Laporan keuangan yang diambil harus memenuhi unsur CAMEL yang terdapat pada laporan keuangan tahunan bank untuk memenuhi syarat dalam penelitian yang akan diteliti.

Objek penelitian ini berdasarkan dari laporan keuangan tahunan bank syariah dan bank konvensional pada tahun 2012-2013 yang terdaftar di Bursa Efek Indonesia. Bank konvensional dan bank syariah yang telah memenuhi syarat sebanyak 10 bank syariah dan 10 bank konvensional. Teknik pengumpulan data yang digunakan dilakukan dengan teknik dokumentasi. Dokumen dikumpulkan dengan cara mengumpulkan data-data sekunder yang berupa laporan keuangan tahunan masing-masing bank yang ingin diteliti dengan diperoleh dari Bursa Efek Indonesia.

Tabel 1. Daftar Bank Syariah dan Bank Konvensional yang Terdaftar di BEI

\begin{tabular}{cl}
\hline No & \multicolumn{1}{c}{ Nama Bank Syariah } \\
\hline 1 & Bank Negara Indonesia Syariah \\
2 & Bank Rakyat Indonesia Syariah \\
3 & Bukopin Syariah \\
4 & Mega Syariah \\
5 & Panin Syariah \\
6 & Victoria Syariah \\
7 & Mandiri Syariah \\
8 & Bank Central Asia Syariah \\
9 & Bank Jabar Banten Syariah \\
10 & Maybank Syariah \\
\hline
\end{tabular}

Sumber: Data yang berada di BEI 
Pengujian dilakukan dengan Uji Independent t-test digunakan untuk menguji signifikansi beda rata-rata dua kelompok, dan untuk membandingkan rata-rata dua sampel dengan syarat bahwa kedua sampel tersebut memiliki varian yang sama (Tomodjudin, 2013; Siregar, 2014). Kriteria pengambilan keputusan adalah

a. Jika nilai signifikan $\mathrm{t}<0,05$ artinya terdapat perbedaan yang signifikan, maka Ho ditolak.

b. Jika nilai signifikan $\mathrm{t}>0,05$ artinya tidak terdapat perbedaan yang signifikan, maka Ho diterima.

\section{Hasil Penelitian dan Pembahasan}

Penelitian ini bertujuan untuk menganalisis perbedaan kinerja bank umum dan bank syariah. Pengujian dilakukan dengan uji beda yang diawali dengan uji normalitas data. Hasil uji normalitas data menunjukkan bahwa data berdistribusi normal. Uji kolmogorov smirnov menunjukkan hasil $>0.05$. Distrbusi data normal digunakan sebagai dasar untuk menentukan uji beda (parametrik) yaitu independent sample $t$-test. Deskripsi variabel dilakukan dengan uji deskriptif. Uji ini dilakukan sebagai langkah awal karena untuk mengetahui nilai minimum, maksimum, rata-rata dan standar deviasi pada masing-masing variabel.

Berdasarkan output SPSS 16.0 pada tabel 2 dapat dilihat bahwa dari jumlah obyek penelitian yang digunakan yaitu sebanyak 40 sampel data terdiri dari 20 bank syariah dan 20 bank konvensional, maka dapat disimpulkan bahwa variabel CAR pada sampel data tersebut memiliki nilai minimum 11,10 dan memiliki nilai maksimum sebesar 31,50 dengan rata-rata 16,88 dengan standart deviasi sebesar 4,04.

Pada variabel ROA dapat disimpulkan bahwa memiliki nilai minimum 0,50 sedangkan nilai maksimum 5,15 dengan rata-rata 2,22 dengan standart deviasi sebesar 1,19. Untuk variabel LDR dapat disimpulkan bahwa memiliki nilai minimum 46,08 sedangkan nilai maksimum 197,70, dengan rata-rata 90,50 dengan standart

Tabel 2. Uji Statistik Deskriptif

\begin{tabular}{lcrrrr}
\hline Variabel & N & Minimum & Maximum & \multicolumn{1}{c}{ Mean } & Std. Deviation \\
\hline CAR & 40 & 11.10 & 31.50 & 16.8865 & 4.04861 \\
ROA & 40 & .50 & 5.15 & 2.2240 & 1.19592 \\
LDR & 40 & 46.08 & 197.70 & 90.5058 & 27.58782 \\
NPL & 40 & .10 & 4.59 & 2.0500 & 1.26398 \\
BOPO & 40 & 47.20 & 110.34 & 77.6603 & 12.93053 \\
\hline
\end{tabular}

Sumber : data diolah

Tabel 3. Kinerja Bank Syariah dan Bank Konvensional

\begin{tabular}{llrrr}
\hline Variabel & \multicolumn{1}{c}{ Bank } & \multicolumn{1}{c}{ Mean } & Std. Deviation & Std. Error Mean \\
\hline CAR & Bank Konvensional & 16.9 & 1.375 & 0.31 \\
& Bank Syariah & 17.60 & 5.55 & 1.24 \\
ROA & Bank Konvensional & 2.70 & 1.18 & .264 \\
& Bank Syariah & 1.75 & 1.04 & .234 \\
\multirow{2}{*}{ LDR } & Bank Konvensional & 78.29 & 11.44 & 2.56 \\
& Bank Syariah & 102.72 & 33.424 & 7.47 \\
NPL & Bank Konvensional & 78.29 & 11.44 & 2.56 \\
& Bank Syariah & 102.72 & 33.424 & 7.47 \\
BOPO & Bank Konvensional & 72.92 & 9.79 & 2.14 \\
& Bank Syariah & 82.40 & 14.28 & 3.19 \\
\hline
\end{tabular}

Sumber : Hasil pengolahan SPSS 16.0 
deviasi sebesar 27,58. Sedangkan untuk variabel NPL dapat disimpulkan bahwa nilai minimum 0,10 dan nilai maksimum 4,59 dengan rata-rata 2,05 dengan standart deviasi sebesar 1,26. Dan pada variabel BOPO dapat disimpulkan bahwa nilai minimum 47,20 sedangkan nilai maksimum 110,34 , dengan rata-rata 77,66 dengan standart deviasi sebesar 12,93.

Berdasarkan hasil perhitungan dengan menggunakan SPSS 16.0 didapat hasil nilai rasio CAR yang berbeda untuk kedua jenis bank tersebut yaitu untuk rasio CAR bank syariah memiliki rata - rata sebesar 17,57 dan untuk bank konvensional memiliki nilai rata - rata rasio CAR sebesar 16,19. Pada rata - rata rasio ROA didapat hasil untuk bank syariah memiliki nilai rata - rata rasio ROA sebesar 1,74 sedangkan untuk bank konvensional memiliki nilai rata - rata rasio ROA sebesar 2,69. Untuk rata - rata rasio LDR bank syariah memiliki nilai sebesar 102,72 dan untuk bank konvensional memiliki rata - rata rasio ROA sebesar 78,28.

Sedangkan rata - rata rasio NPL bank syariah memiliki nilai sebesar 2,62 dan bank konvensional memiliki nilai rata - rata rasio ROA sebesar 1,47. Dan untuk rata - rata rasio BOPO pada bank syariah memiliki nilai sebesar 82,40 dan bank konvensional memiliki rata - rata rasio BOPO sebesar 72,91.

Uji Independent t-test digunakan untuk menguji signifikansi beda rata - rata dua kelompok, dan untuk menguji apakah hipotesis yang telah dibuat dapat diterima atau ditolak. Uji independent t-test ini digunakan karena hasil pada uji normalitas data sebelumnya mendapatkan hasil bahwa data berdistribusi normal.

Berdasarkan uji independent t-test pada tabel diatas dapat dilihat bahwa dalam sig F-hitung untuk nilai variabel CAR sebesar 17,77 dengan probabilitas $0,00<0,05$ yang artinya kedua populasi memiliki varians yang berbeda. Nilai thitung Equal variances assumed sebesar 1.08 dengan profitabilitas signifikansi $0,28>$ 0,05 maka Ho diterima sehingga dapat diartikan bahwa tidak terdapat perbedaan yang signifikan antara bank syariah dengan bank konvensional.

Pada rasio ROA dapat dilihat bahwa sig F-hitung memiliki nilai sebesar 0,16 dengan probabilitas $0,69>0,05$ yang artinya kedua populasi memiliki varians yang sama. Nilai thitung Equal variances assumed sebesar 2.71 dengan profitabilitas signifikansi $0,01<0,05$ maka Ho ditolak sehingga dapat diartikan bahwa terdapat perbedaan yang signifikan antara bank syariah dengan bank konvensional jika dilihat berdasarkan rasio ROA.

Pada variabel LDR dapat dilihat bahwa sig F-hitung memiliki nilai sebesar 4,39 dengan probabilitas $0,04<0,05$ yang artinya kedua populasi memiliki varians yang berbeda. Nilai thitung Equal variances assumed sebesar 3,09 dengan probabilitas signifikansi $0,00<0,05$ maka Ho ditolak sehingga dapat dinyatakan bahwa pada rasio LDR terdapat perbedaan yang signifikan antara bank syariah dengan bank konvensional.

Pada rasio NPL juga dapat dilihat bahwa sig F-hitung memiliki nilai sebesar 5,00 dengan probabilitas $0,03<0,05$ yang artinya kedua populasi memiliki varians yang berbeda. Nilai thitung Equal variances assumed sebesar 3,22 dengan probabilitas signifikansi $0,00<0,05$ maka Ho ditolak sehingga dapat diartikan bahwa pada rasio NPL terdapat perbedaan yang signifikan antara bank syariah dengan bank konvensional.

Pada rasio BOPO dapat dilihat bahwa sig F-hitung memiliki nilai sebesar 0,70 dengan probabilitas $0,40>0,05$ yang artinya kedua

Tabel 4. Hasil Uji Beda

\begin{tabular}{llrrr}
\hline Variabel & Sig. & $\mathrm{T}$ & Sig. (2-tailed) & Keterangan \\
\hline CAR & .000 & -1.084 & .285 & Tidak Beda \\
ROA & .691 & 2.712 & .010 & Beda \\
LDR & .043 & -3.093 & .004 & Beda \\
NPL & .031 & -3.228 & .003 & Beda \\
BOPO & .406 & -2.466 & .018 & Beda \\
\hline
\end{tabular}

Sumber : Hasil pengolahan spss 16.0 
populasi memiliki varians yang sama. Nilai thitung Equal variances assumed sebesar 2,46 dengan probabilitas signifikansi $0,01<0.05$ maka Ho sehingga dapat diartikan bahwa pada rasio BOPO terdapat perbedaan yang signifikan antara bank syariah dengan bank konvensional.

\section{Simpulan, Keterbatasan, dan Implikasi Hasil Penelitian}

Berdasarkan pembahasan dari hasil penelitian dapat diambil beberapa kesimpulan yaitu:

1. Berdasarkan hasil uji independent t-test menunjukan bahwa rata - rata rasio CAR pada bank syariah dengan bank konvensional dinyatakan bahwa tidak terdapat perbedaan yang signifikan. Rata-rata rasio CAR keseluruhan pada tahun 2012-2013 bank syariah lebih tinggi dibandingkan dengan bank konvensional.

2. Berdasarkan hasil uji independent t-test menunjukan bahwa rata - rata rasio ROA pada bank syariah dengan bank konvensional dinyatakan bahwa terdapat perbedaan yang signifikan. Rata-rata rasio ROA keseluruhan pada tahun 2012-2013 bank konvensional lebih tinggi dibandingkan bank syariah.

3. Berdasarkan hasil uji independent t-test menunjukan bahwa rata - rata rasio LDR pada bank syariah dengan bank konvensional dinyatakan bahwa terdapat perbedaan yang signifikan. Rata-rata rasio LDR keseluruhan pada tahun 2012-2013 bank syariah lebih tinggi dibandingkan dengan bank konvensional.

4. Jika dilihat berdasarkan hasil uji independent t-test rata - rata rasio NPL pada bank syariah dengan bank konvensional dinyatakan bahwa terdapat perbedaan yang signifikan. Rata-rata rasio NPL keseluruhan pada tahun 2012-2013 bank konvensional lebih rendah dibandingkan dengan bank syariah.

5. Jika dilihat berdasarkan hasil uji independent t-test rata - rata rasio BOPO pada bank syariah dengan bank konvensional dinyatakan bahwa terdapat perbedaan yang signifikan.
Rata-rata rasio CAR keseluruhan pada tahun 2012-2013 bank konvensional lebih rendah dibandingkan bank syariah.

6. Berdasarkan hasil penelitian perbandingan rasio CAR, ROA, LDR, NPL, dan BOPO dengan standar ketentuan yang telah ditetapkan oleh BI. Bank syariah mempunyai kinerja yang kurang baik karena bank memiliki rasio CAR dan rasio LDR tinggi yang artinya bank memiliki modal yang tinggi dan dana yang disalurkan tinggi tetapi bank tidak mampu mengelola modal dengan baik sehingga rasio NPL atau kredit yang bermasalah yang dimiliki oleh bank juga tinggi dan hal ini yang menyebabkan rasio ROA pada bank syariah rendah.

Berdasarkan hasil penelitian, kelemahan, dan kontribusi yang diharapkan dari hasil penelitian, berikut adalah berikut adalah saran dari hasil penelitian ini.

1. Bank syariah secara umum mempunyai kinerja lebih baik dibandingkan dengan bank konvensional. Hal ini dapat dilihat dari nilai pada rasio CAR bank syariah yang mempunyai rata - rata rasio CAR lebih tinggi dibandingkan bank konvensional. Bagi babk konvensional disarankan untuk menekan resiko kredit karena resiko ini salah satu yang mempengaruhi jumlah besar atau kecilnya ATMR jika nilai ATMR kecil maka rasio CAR meningkat.

2. Bank syariah mempunyai kinerja kurang baik jika dilihat dari nilai rata - rata rasio ROA sebaiknya bank dapat meningkatkan rasio ROA karena semakin tinggi nilai ROA semakin bagus kualitas manajemen bank dalam memperoleh keuntungan. Bank syariah disarankan untuk meningkatkan kredit dan modal bank serta meningkatkan pengendalian terhadap kredit yang bermasalah pada bank.

3. Kinerja bank syariah pada rasio LDR lebih baik dibandingkan dengan bank konvensional. Hal ini dapat dilihat pada ratarata rasio LDR bank syariah yang lebih kecil dibandingkan dengan bank konvensional. Bank konvensional disarankan untuk meningkatkan rasio CAR karena tingginya 
modal yang dimiliki bank akan berpengaruh terhadap jumlah kredit yang akan disalurkan kepada nasabah.

4. Pada rasio NPL bank syariah mempunyai nilai yang lebih besar dibandingkan dengan bank konvensional, bagi bank syariah disarankan untuk mengurangi nilai pada rasio NPL karena semakin tinggi nilai rasio NPL maka semakin buruk kualitas aktiva produktif dengan kualitas aktiva yang bermasalah.

5. Kinerja bank syariah jika diukur berdasarkan BOPO lebih baik dibandingkan dengan bank konvensional. Hal ini dapat dilihat dari ratarata rasio BOPO bank syariah yang lebih kecil dibandingkan bank konvensional. Bagi bank konvensional disarankan untuk meningkat tingkat efisien biaya operasionalnya karena hal ini dapat mempengaruhi keuntungan bank.

Penelitian mendatang juga dapat mempertimbangkan perbedaan dengan sampel lain sebagaimana halnya yang dilakukan oleh Parathon (2013) yang membuktikan pengujian terkait tingkat kesehatan satu bank pembangunan daerah. Riset mendatang dapat melakukan analisis dengan menggunakan sampel BPD di Indonesia dan membandingkannya dengan jenis bank lain yang ada di Indonesia.

\section{Daftar Rujukan}

Bank, Indonesia, Booklet Perbankan Indonesia. 2011. Jakarta: Bank Indonesia , Peraturan Bank Indonesia No. 9/7/ PBI/2007 tentang Pengertian Bank Umum

Hasibuan, M. (2007). Dasar-dasar Perbankan, Edisi kelima. Jakarta: Bumi Aksara

Herman, D. (2011). Manajemen Perbankan, Jakarta: Bumi Aksara

Kasmir. (2010). Dasar-dasar Perbankan, Edisi Revisi 9. Jakarta: Rajawali Pers

Maharani, K. (2010). Analisis Kinerja Keuangan Perbankan Syariah Dengan Perbankan Konvensional. Tesis. Program Magister Akuntansi. Universitas Diponogoro.

Muhamad. (2014). Manajemen Dana Bank Syariah. Edisi Pertama. Jakarta: PT. Raja
Gerindo Persada

Ningsih, I. W. (2012). Analisis Perbandingan Kinerja Keuangan Bank Umum Syariah Dengan Bank Umum Konvensional Di Indonesia Doctoral dissertation. Universitas Hasanudin

Pandia, Frianto. (2012). Manajemen Dana Dan Kesehatan Bank, Edisi Pertama. Jakarta: Rineka Cipta

Parathon, A. A. (2013). Analisis Rasio Keuangan Perbankan Sebagai Alat Ukur Kinerja Keuangan Bank Studi Kasus PT. Bank Pembangunan Daerah Jawa Timur, Tbk Surabaya Periode 2009-2012. Jurnal Administrasi Bisnis, 32. 1-11

Putra, A. P., Lahindah, L., \& Rismadi, B. (2014). Financial Performance Analysis Before and After Global Crisis Case Study in Indonesian Oil and Gas Sector for the Period of 20062011. Review of Integrative Business and Economics Research, 31, 42-51

Siregar, S. 2014. Statistik Parametik Untuk Penelitian Kuantitatif. Edisi Kedua. Jakarta: PT. Bumi Aksara

Tomodjudin. (2013). Statistika ParametikDasar Pemikiran dan Penerapannya dalam Penelitian. Edisi Pertama. Yogyakarta: Tiara Wacana

Widiyanti,M., \& Wulansari, R. (2015). R. Analysis of Capital, Asset Quality, Rentability and Liquidity For Health Research of Pt. General Sharia-Based Bank in Indonesia. Prosiding Perkem 10, 590 - 607.

Yulianto, A. (2009). Analisis Perbandingan Kinerja Keuangan Perbankan Konvensional dengan Perbankan Syariah Sebelum dan Saat Krisis Finansial Global Tahun 2006-2009 